Vladimir R. Belyaev ${ }^{1 *}$, Alexander S. Zavadsky ${ }^{1}$, Maxim V. Markelov ${ }^{1}$, Rolf T. Ottesen ${ }^{2}$, Jim J. Bogen ${ }^{3}$, Valentin N. Golosov' ${ }^{1}$ Elena N. Aseeva', Yulia S. Kuznetsova ${ }^{1}$.

${ }^{1}$ Faculty of Geography, M.V. Lomonosov Moscow State University, Moscow, Russia, GSP-1, Leninskie Gory, 1, 119991; phone +7 495 9395044;

* Corresponding author, e-mail: valdemar_b@rambler.ru.

${ }^{2}$ Geological Survey of Norway, N-7491, Trondheim, Norway; phone: +47 73904302; e-mail: Rolf.Ottesen@ngu.no.

${ }^{3}$ Norwegian Water Resources and Energy Directorate (NVE) P.O. Box 5091, Majorstua, NO-0301, Oslo, Norway; phone: +47 22959046; e-mail: jbo@nve.no.

\title{
ASSESSMENT OF OVERBANK SEDIMENTATION RATES AND ASSOCIATED POLLUTANT TRANSPORT WITHIN THE SEVERNYA DVINA RIVER BASIN
}

\begin{abstract}
It is now widely recognized that significant proportion of pollutants in rivers is transported with suspended sediments. This paper presents a combination of reconstruction of recent floodplain sedimentation rates based on detailed description of sediment sections and ${ }^{137} \mathrm{Cs}$ stratigraphy with geochemical analysis of overbank deposits at selected sites on rivers of the Severnaya Dvina River basin. Overbank sedimentation rates for sections sampled on floodplains of the Severnaya Dvina and Vychegda Rivers are characterized by noticeable decrease from $\approx 1.5-4.0 \mathrm{~cm}$ year $^{-1}$ between 1954 and 1963 to $<1.0 \mathrm{~cm}$ year $^{-1}$ at present. It can be explained by the natural evolution of the floodplain segments sampled. In contrast, highest modern floodplain aggradation rates $\left(\approx 1.8 \mathrm{~cm}\right.$ year $\left.{ }^{-1}\right)$ observed for the relatively small Toshnya River are definitely associated with human impact - locally intensive agriculture. Evaluation of geochemical properties of overbank sediments has shown that general levels of the sediment contamination by heavy metals are low.
\end{abstract}

KEYWORDS:suspended sediment; floodplain; overbank deposition; ${ }^{137} \mathrm{Cs}$, particle-bound pollutants; Severnaya Dvina River

\section{INTRODUCTION}

Fluvial systems are dynamic geomorphic cascades where sediment and associated compounds are moved from sources to sinks and eventually delivered into the receiving sedimentary basins (lakes, seas, oceans, less frequently no-drainage continental depressions). Main natural controls of the spatial and temporal patterns of fluvial sediment transport are climate, geological, geomorphic and landscape settings of drainage basins and hydrological regime [Makkaveev, 1953; Schumm, 1977; Milliman \& Syvitski, 1992]. Deforestation, agricultural development, urbanization, hydropower development, river regulation, mining and other human activities can profoundly affect the processes of erosion and deposition in river systems and may cause co nsiderable changes, both in sediment redistribution within river basins and in sediment export into the ocean [Milliman \& Meade, 1983; Dedkov \& Mozzherin, 1984, Syvitski et al., 2005]. 
It is now widely recognized that significant proportion of pollutants in rivers is transported in association with fine-grained suspended sediments [Carter et al., 2003; Salomons \& Brils, 2004]. Hence, overbank deposition of suspended sediments on river floodplains creates a sedimentary record which can represent a very informative sampling medium for evaluating pollution levels from various periods [Ottesen et al., 1989; Bogen et al., 1992]. In addition overbank sediments of larger rivers are believed to be representative for their drainage areas since they integrate contribution of numerous smaller tributaries [Ridgway et al., 1995; Xie \& Hangxin, 2001]. By sampling sufficiently deep cores in overbank sediment it is possible to characterize recent levels of sediment-associated pollution, its variation over the period of industrial development, and geochemical composition of sediment under pre-industrial pristine conditions [Ottesen et al., 1989; Bogen et al., 1992; Carter et al., 2003]. If reliable dating of overbank sediment cores is available in order to build up recent sediment stratigraphy, it becomes possible to quantitatively determine the changes that have taken place and, possibly to indicate future trends. If the sediment transport in a particular river system of interest has been monitored over sufficient period of time, the geochemical analyses of overbank sediment can be converted into fluxes of various chemical elements.

In this paper we present results of the investigation of floodplain sedimentation rates at selected sites on rivers of the Severnaya Dvina River basin combined with geochemical analysis of depth-incremental sediment samples. Such a combination allows evaluating the level of sedimentassociated contamination of the river basin area, determining point sources of pollution and making some conclusions on delivery of particle-bound pollutants into the Arctic Ocean [Holmes et al., 2002]. Sampling sites were located in different parts of the Severnaya Dvina River basin, in most cases upstream and downstream from the cities with important industrial objects.

\section{STUDY AREA LOCATION AND DESCRIPTION}

The Severnaya (Northern) Dvina River basin is located in northern part of the European Russia. The river drains vast areas of predominantly forested and scarcely populated plains and lowlands of northern part of the Eastern European or Russian Plain and flows into the White Sea of the Arctic Ocean (Fig. 1). The Severnaya Dvina River itself begins near the Velikiy Ustyug City at the confluence of its two main sources - the Suhona River sourcing from the Kubenskoe Lake at the southwestern part of the basin and the Yug River with head at the Severnye Uvaly Upland at the basin southern margin. From that point it is named the Malaya (meaning Little in Russian) Severnaya Dvina until it receives from the east its largest right tributary - the Vychegda River (in fact having even larger discharge than the main river in many cases) - about $60 \mathrm{~km}$ downstream near the Kotlas City (Fig. 1b).

Total basin area is approximately $357000 \mathrm{~km}^{2}\left(5^{\text {th }}\right.$ largest in the Europe after the Volga, Danube, Dnieper and Don River basins). Total length of the Severnaya Dvina River (with the longer of its two main sources - the Suhona River) is about $1300 \mathrm{~km}$, which makes it only $8^{\text {th }}$ largest in the Europe (after the Volga, Danube, Ural, Dnieper, Don, Pechora and Rein Rivers). Average annual discharge at the delta apex is about $3420 \mathrm{~m}^{3} \mathrm{~s}^{-1}$, yielding annual flow into the White Sea of about $108 \mathrm{~km}^{3}$ year ${ }^{-1}$ (discharge measurements available from 1881). Peak discharges during the spring flood vary between 11000 and $36000 \mathrm{~m}^{3} \mathrm{~s}^{-1}$, with average value of about $22000 \mathrm{~m}^{3} \mathrm{~s}^{-1}$ [Holmes et al., 2002]. Information on suspended sediment yield (SSY) is much more limited (record begins from 1950, with several gaps). Direct measurements of bedload sediment transport were very limited; most of the available information is based on analysis of the bedforms migration [Alexeevskiy, 1998]. Average annual SSY measured for the lowest gauging station (Ust-Pinega, $\approx 90 \mathrm{~km}$ upstream from the delta apex) is $\approx 3.9 \mathrm{Mt}$ year $^{-1}$, estimated average annual 


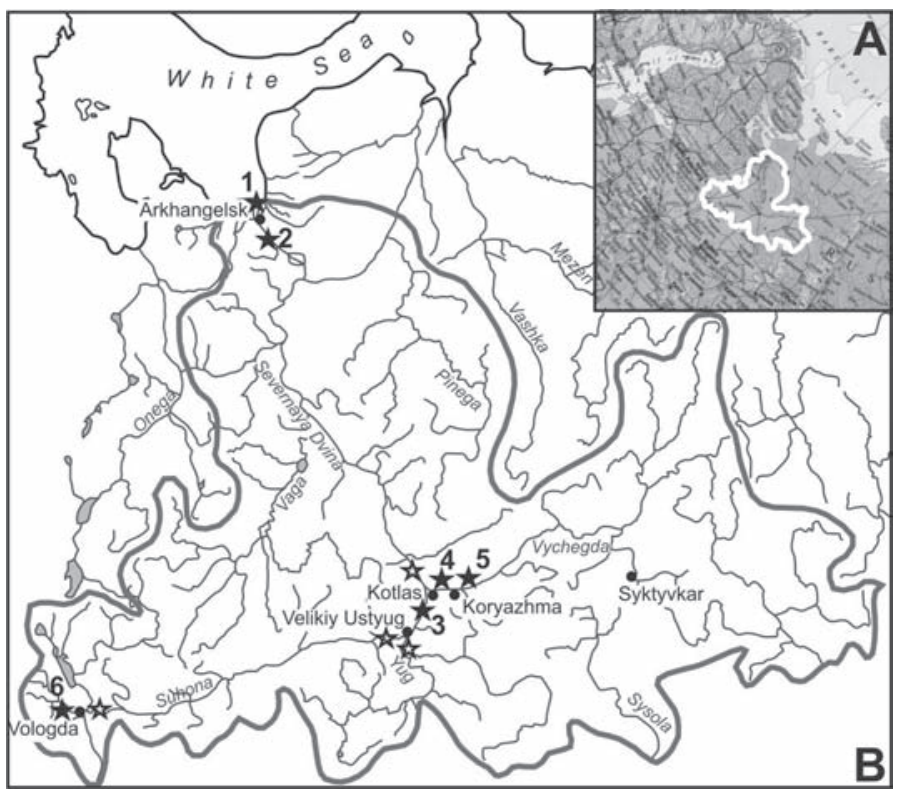

Fig. 1. The Severnaya Dvina River basin general location within the Northern European Russia (a) and hydrographic scheme $(b)$.

Stars designate floodplain sections sampled. Filled stars with numbers mark locations of the sections for which the sample analyses has already been completed: 1) SevDV-1; 2) SevDV-2; 3) MSevDV-1; 4) VYCH-1; 5) VYCH-2; 6) TOSH-1

bedload sediment yield (BSY) is $\approx 0.7 \mathrm{Mtyear}^{-1}$ (about $17 \%$ of the SSY), total sediment yield is $\approx 4.6 \mathrm{Mt} \mathrm{year}^{-1}$ [Reznikov \& Chalov, 2005]. Average annual sediment export from the Severnaya Dvina River delta into the White Sea can be approximated as $\approx 4.8 \mathrm{Mt}$ year $^{-1}$, of which $\approx 4.3 \mathrm{Mt} \mathrm{year}^{-1}$ is suspended sediment and $\approx 0.5$ Mt year $^{-1}$ is bedload. About $90 \%$ of the SSY and all the BSY occurs during the spring snowmelt and autumn floods. Total annual sediment export can vary between $\approx 2.0$ and $\approx 9.0 \mathrm{Mt}^{\text {year }}{ }^{-1}$ depending on flood discharges [Bobrovitskaya, 1996].

\section{Geological and geomorphic characteristics}

From geological point of view, the Severnaya Dvina River basin occupies mainly axial and northern parts of the Moscow Syneclise. The main valley stretched in the northwestern direction crosses monoclinal beds of the Upper Permian and Lower Triassic sedimentary rocks dipping southeastward towards the Moscow Syneclise axis. Quaternary drifts cover sedimentary bedrock by thick (up to tens and at places hundreds of meters) layer composed mainly of glacial boulder clay deposits with marine sands and clays at lowland territories along the White Sea coastal zone and in major valleys. There are also glaciofluvial, glaciolacustrine and alluvial Quaternary deposits widespread within the region. Upper till layer with associated glaciofluvial and glaciolacustrine deposits are in most cases covered by up to 2-4 $\mathrm{m}$ thick superficial layer of the so-called sheet loams containing no coarse particles. Their exact origin is still questionable, but most likely can be attributed to a complex of processes (frost weathering, aeolian transport and deposition, sheet wash, solifluction) occurring under periglacial conditions after the glacial retreat. These sheet loams represent the most widespread parent material for the regional soil formation.

Geomorphology of the Severnaya Dvina River basin is substantially uniform and dominated by lowland undulating plain topography. This general uniformity is interrupted only by hilly upland terrain of the Timanskiy Kryazh Upland along the southeastern margin of the basin, where elevation of the main interfluve between the Severnaya Dvina and 
the Pechora basins rises up to $350-450 \mathrm{~m}$ a.s.l.. Large areas of undulating lowland plains (elevation <100 $\mathrm{m}$ a.s.l., along the White Sea costal zone $<30 \mathrm{~m}$ a.s.l.) alternate with smaller territories occupied by low plateaus, rolling and hilly plains (elevation 100-150, locally up to $250 \mathrm{~m}$ a.s.I.). Transitional zones between lowlands and low plateaus are commonly represented by morphologically distinctive steps with relative height up to 50-100 m. Presently existing river valleys occupy wide depressions of ancient valleys formed mainly during the MesozoicCenozoic. During the Quaternary glacialinterglacial alternations those valleys were subject to repetitive infill by marine, glacial, glaciofluvial, alluvial deposits of extremely variable lithology (from loose sands to relatively resistant glacial boulder clays) and partial reworking. Superimposed onto changing bedrockgeology, this spatial variety of the Quaternary valley infills determines complex spatial pattern of free and restricted conditions of channel deformations on rivers of the Severnaya Dvina basin. As a result of that, wide variety of morphodynamic channel patterns is present within the basin including various subtypes of incised, adjusted and free channels.

\section{Climate, soils and vegetation}

Main climatic characteristics of the Severnaya Dvina River basin are low amount of solar radiation over the prolonged winter period, profound influence of the ocean and predominance of intensive transport of air masses from west to east over most of the year. Typical seasonal weather pattern of the region is characterized by short cool summer with frequent rains (3-4 months, average temperature of a warmest month not exceeding $+16-17^{\circ} \mathrm{C}$, precipitation up to 400-500 mm), and long cold winter (5-6 months, average temperature of a coldest month about $-20^{\circ} \mathrm{C}$, precipitation 100-200 mm) with stable snow cover. Total annual precipitation is within a range of 600 $750 \mathrm{~mm}$, about $65-70 \%$ of which occurs during warm seasons. Low-intensity longlasting rainfalls are dominant, while intensive rainstorms are rare. Permanent snow cover is normally established in the late September early October and stays until late April - early May. Maximum thickness of snow can reach $75-85 \mathrm{~cm}$ in forests and $55-65 \mathrm{~cm}$ in open spaces. Water storage in the snow cover at the beginning of snowmelt period is 140$200 \mathrm{~mm}$ in forests and $120-180 \mathrm{~mm}$ in open spaces. Seasonal freezing of soils and surface grounds begins in the late September. Its complete melting commonly ends in early May. Maximum depth of seasonally frozen layer can reach 120-200 cm (in February March).

The entire basin is situated within the boreal forest (taiga) zone dominated by coniferous forests on podzolic, gley-podzolic and sodpodzolic soils. Natural vegetation of the area is mainly represented by coniferous forests, dominated by spruce and pine, with subordinate birch and alder. Pine forests are widespread on glaciofluvial sandy plains and wide river terraces. Degree of forestation within the region is generally around $80 \%$, increasing locally up to $>95 \%$. Most of the open areas on flat poorly drained interfluves are occupied by vast blanket peat bogs (5-10\%). Vegetation of blanket bogs is represented mainly by sphagnum moss and sedges with suppressed sparsely growing pine trees. Meadows occupy parts of medium and large river floodplains as well as some forest cutting areas on relatively steep valley slopes. However, most of the forest cuttings very rapidly become regrown by birch-pine secondary forest. The latter becomes eventually substituted by typical zonal forest dominated by spruce at later stage of biological succession.

\section{Human activities}

Administratively, the Severnaya Dvina River basin is located within the four Regions of the Russian Federation - the Arkhangelsk, the Komi, the Vologda and the Kirov Regions, of which the first comprises most of its territory. The average population density is very low $\left(<5 \mathrm{p} \mathrm{km}^{-2}\right.$ for about $90 \%$ of the basin area). There are only 3 cities with 
population >100000 within the basin Vologda, Syktyvkar and Arkhangelsk. Development of the territory is very uneven. Industry is concentrated in the 3 main urban centers mentioned above and a few smaller industrial towns such as Koryazhma and Kotlas. Agricultural development is extremely limited (basin-scale percentage of arable land is $\approx 5 \%$ ) by unfavorable climatic conditions, predominantly poor soils and widespread waterlogging of landscapes. Significant areas of agricultural land are present only in southwestern corner of the basin in areas surrounding the Vologda City, where it can locally reach $40-50 \%$.

The most important specialization of the region is forest industry (timber harvesting) for constructional purposes (with large proportion of that being exported) and as a primary product for paper and pulp industry (used locally at a few large pulp and paper plants such as those at the Koryazhma, Syktyvkar, Novodvinsk etc.). The most intensive forest cuttings took place during 1970-1980s., mainly within the most developed parts of the basin (surroundings of the Arkhangelsk, Vologda, Syktyvkar, Kotlas) and along major railways. The Severnaya Dvina River is an important transportation route, timber and paper products constituting large percentage of the total cargo volume.

\section{Major sediment and pollution sources}

Analysis of general information on physiographic conditions and human activities in the Severnaya Dvina River basin makes it possible to conclude that, in contrast to densely populated and intensively cultivated territories of the Central European Russia, such sediment sources as soil and gully erosion on catchment slopes are unimportant for the basin-scale sediment budget. Their contribution can be considerable only locally in southwestern part of the basin, where percentage of cultivated land is noticeable. Main source of fluvial sediment is bank erosion, which is most intensive on largest rivers of the basin at reaches characterized by free meandering channel types. Consequently, main temporarily sediment sink is represented by vast floodplains of largest rivers characterized by comparatively active reworking as a result of interaction of bank erosion, overbank deposition and lateral floodplain accretion by bedform stabilization. From a point of view of main pollution sources, very low percentage of cultivated land means that pollution of watercourses within the basin is primarily associated with point sources represented by several centers of industrial development with precisely known locations. Certain degree of floodplain sediment pollution can also be caused by airborne contaminants originating from distant sources, which are significantly more difficult to identify [Langedal \& Ottesen, 1998]. Additional sediment and (potentially) pollution source specifically for the Severnaya Dvina River basin can be represented by forest cutting areas. However, information for quantification of associated erosion and pollution is at present unavailable.

\section{OVERBANK SEDIMENT SAMPLING AND ANALYSES}

\section{Overbank sediment sampling locations and strategy}

A number of sampling locations has been selected at floodplains of different rivers within the Severnaya Dvina River basin with aim to characterize variability of overbank deposition rates, geochemical properties of floodplain sediment and to determine possible negative impacts of the major industrial centers as point-sources of water and sediment pollution. By now, 10 sections have already been sampled, of which laboratory analyzes have already been completed for six (Fig. 1b). Of those, 1 section (SevDV-1) was located at the Severnaya Dvina River delta apex, 1 on the Severnaya Dvina lower reach upstream the Arkhangelsk City (SevDV-2), 1 section on the Severnaya Dvina River upper reach upstream from its confluence with the main right tributary - the Vychegda River - 
(MSevDV-1), 2 sections on the Vychegda River lower reach downstream (VYCH-1) and upstream ( $\mathrm{VYCH}-2)$ from the largest paper and pulp plant at the Koryazhma town and 1 section on the relatively small Toshnya River located in headwaters of the Sukhona River (one of the Severnaya Dvina River main sources) in surroundings of the Vologda City characterized by relatively high degree of agricultural development. Detailed visual description of each of the selected sections was undertaken prior to the sampling procedure. Sampling was carried out from naturally undercut floodplain banks where visual analyses showed that at least $0.5 \mathrm{~m}$ of fine laminated overbank sediment has been deposited above the underlying sandy cross-bedded channel sediment. The entire sediment column was sampled uniformly with individual samples taken at depth increments of $5 \mathrm{~cm}$ from fixed surface area of $10 \times 10 \mathrm{~cm}^{2}$. In most cases $1 \mathrm{~m}$ of sediment was sampled, covering overbank fine sediment layer and top of the underlying sandy channel deposits. In a few cases, however, longer or shorter columns were sampled, depending on results of section description.

\section{Methods of laboratory analyses of overbank sediment samples}

Gamma-spectrometric analysis of ${ }^{137} \mathrm{Cs}$ content in overbank sediment samples

Representative subsamples with a weight above $100 \mathrm{~g}$ were isolated from $10 \times 10 \times 5$ $\mathrm{cm}$ depth-incremental sediment samples taken for geochemical analysis as described above. Subsamples were dried at $105^{\circ} \mathrm{C}$, ground in order to destroy large aggregates and thoroughly mixed to homogenize the material. Particles exceeding $2 \mathrm{~mm}$ in diameter were removed by sieving samples through the $2 \mathrm{~mm}$ mesh sieve.

Radionuclide gamma-spectrometric analysis of the samples was undertaken at the Faculty of Geography, Lomonosov Moscow State University. Measurements of ${ }^{137} \mathrm{Cs}$ activity were carried out along the $661.66 \mathrm{KeV}$ line of the gamma-ray energy spectrum using a gamma-spectrometric device produced by the Institute of Physical and Technical Problems, Dubna, Moscow Region, Russia. The device is based on the high-resolution, low-background, low-energy, hyperpure germanium coaxial gamma-ray detector (BDEG-30.195) with a resolution of $1.95 \mathrm{KeV}$ along the $1332 \mathrm{KeV}$ line and an efficiency of $30 \%$, coupled to an amplifier and multichannel analyzer. Prior to the sample analysis, the detector was calibrated using the official calibration standard samples provided by the IAEA. For activity measurements samples were placed into cylindrical plastic containers of a standard geometry and placed on the top of the detector column. Counting times were determined by a reliable detection of the ${ }^{137} \mathrm{Cs}$ peak, but not less than 8 hours. Concentrations and inventories of ${ }^{137} \mathrm{Cs}$ were then calculated for each sample from its measured activity following the standard procedure as described by Murray et al. [1987].

Interpretation of 137Cs depth distributions in floodplain sediment sections

There are a number of cases of successful applications of ${ }^{137} \mathrm{Cs}$ depth distribution curves for dating sediment layers in zones of continuous deposition, including lakes, dry valley bottoms and river floodplains, reported in the literature [Walling et al., 1992; Walling \& He, 1997, 1998; Michel et al., 2002; Belyaev et al., 2005]. For the present study, interpretation of each of the ${ }^{137} \mathrm{Cs}$ depth distribution curves obtained from the gamma-analysis of the samples of floodplain sediment sections involves: i) construction of the ${ }^{137} \mathrm{Cs}$ depth distribution curve and calculation of the total isotope inventory at the sampling points from the measured activity concentrations, bulk densities and known volumes of individual samples; ii) comparison of the calculated total isotope inventory at each sampling point with the available information on regional values of the bomb-derived and Chernobyl fallout inventories published in the "Atlas of Caesium deposition on Europe after the Chernobyl accident" [1998] in order to determine the possible relative contribution 
of the global fallout, Chernobyl fallout and lateral input of sediment-bound ${ }^{137} \mathrm{Cs}$ into the total point inventory; iii) interpretation of the ${ }^{137} \mathrm{Cs}$ depth distribution peaks' location in the sediment profile and correspondent activity concentrations, in combination with the available field data including detailed visual description of asediment profileandfloodplain morphology at a sampling location; iv) the final attribution of the available depth profile peaks to corresponding years of maximum fallout (possible options are 1959, 1963, 1986) and subsequent construction of the recent sediment stratigraphy (additional time mark is provided by the ${ }^{137} \mathrm{Cs}$ commencement in 1954); and finally v) calculation of average sedimentation rates, with accounting for possible vertical migration of the ${ }^{137} \mathrm{Cs}$ fallout peaks if such information is available.

Geochemical analyses of overbank sediment samples

Geochemical analyses of the floodplain sediment samples were conducted at the Geological Survey of Norway facilities in Trondheim. After drying, the samples were sieved and the $<0.062 \mathrm{~mm}$ fraction analyzed for the total contents of 30 elements and an acid soluble fraction of 29 elements. Preparation ofanacidsolublefractioninvolved acid extraction in $7 \mathrm{~N} \mathrm{HNO3}$ in autoclave according to Norsk Standard - NS 4770 (1 g sample extracted with $20 \mathrm{ml} 7 \mathrm{~N} \mathrm{HNO} 3$ in autoclave for $30 \mathrm{~min}$ under $120^{\circ} \mathrm{C}$, cooled to room temperature and left overnight before filtration and diluted to $100 \mathrm{ml}$ with distilled water). Analytical techniques applied included the inductively coupled plasma optical emission spectroscopy (ICP-OES) performed using the Perkin-Elmer Optima 4300 Dual View instrument, and the graphite furnace atomic absorption spectroscopy (GFAAS) performed using the Perkin-Elmer SIMA 6000 instrument.

\section{RESULTS AND DISCUSSION}

\author{
Overbank sediment stratigraphy based on \\ ${ }^{137} \mathrm{Cs}$ depth distribution and reconstruction \\ of recent floodplain aggradation rates
}

Depth distribution curves of ${ }^{137} \mathrm{Cs}$ in 6 floodplain sections for which the laboratory analyses of samples have already been completed are presented on Fig. 2. Sampling points locations are shown numbered on Fig. 1b. It can be seen from the figure that 4 of the 6 sampled sections are characterized by 1 (sections SevDV-1 and TOSH-1, Fig. 2a, f), 2 (section MSevDV-1, Fig. 2e) or 3 (section VYCH-1, Fig. 2c) clearly identifiable peaks of ${ }^{137} \mathrm{Cs}$ at certain depths, and another one has maximum located at the top of the section (sections SevDV-2, Fig. 2b). These peaks can be attributed to one of the years characterized by maximums of the ${ }^{137} \mathrm{Cs}$ atmospheric fallout - 1959, 1963 or 1986.

Significant variability of total ${ }^{137} \mathrm{Cs}$ inventory is observed between the sampled sections. For the 3 sections (SevDV-1, VYCH-1 and MSevDV-1, Fig. 2 a, C, e) total ${ }^{137} \mathrm{Cs}$ inventory at the sampling point is close to the regional values reported (Atlas.., 1998) suggesting that additional lateral input of the isotope with deposited fine sediment has been very limited. For the other 2 sections (SevDV-2, VYCH-2, Fig. 2 b, d) total isotope inventory is substantially lower than the regional values. In case of the section SevDV-2 it can most likely be explained by removal of the upper part of the overbank sediment layer by erosive action of the floating ice during one of the recent floods, as depth penetration of the ${ }^{137} \mathrm{Cs}$ is very low and the peak is found on top of the sampled section (Fig. 2b). In contrast, for the section $\mathrm{VYCH}-2$ it is obvious that the sampling depth was insufficient to reach the base of the ${ }^{137} \mathrm{Cs}$ depth distribution (Fig. 2d). This section is characterized by low thickness of the fine overbank sediment layer $(<0.5 \mathrm{~m})$ underlain by cross-bedded sandy channel deposits. Thus it can be suggested that this particular floodplain segment is very young and formed after the isotope fallout has already ceased. Generally low concentrations of ${ }^{137} \mathrm{Cs}$ in the sediment prove that it has been originated not from the atmospheric fallout, but mostly from lateral input and redeposition of material from other floodplain segments eroded upstream (Fig. 2d). 

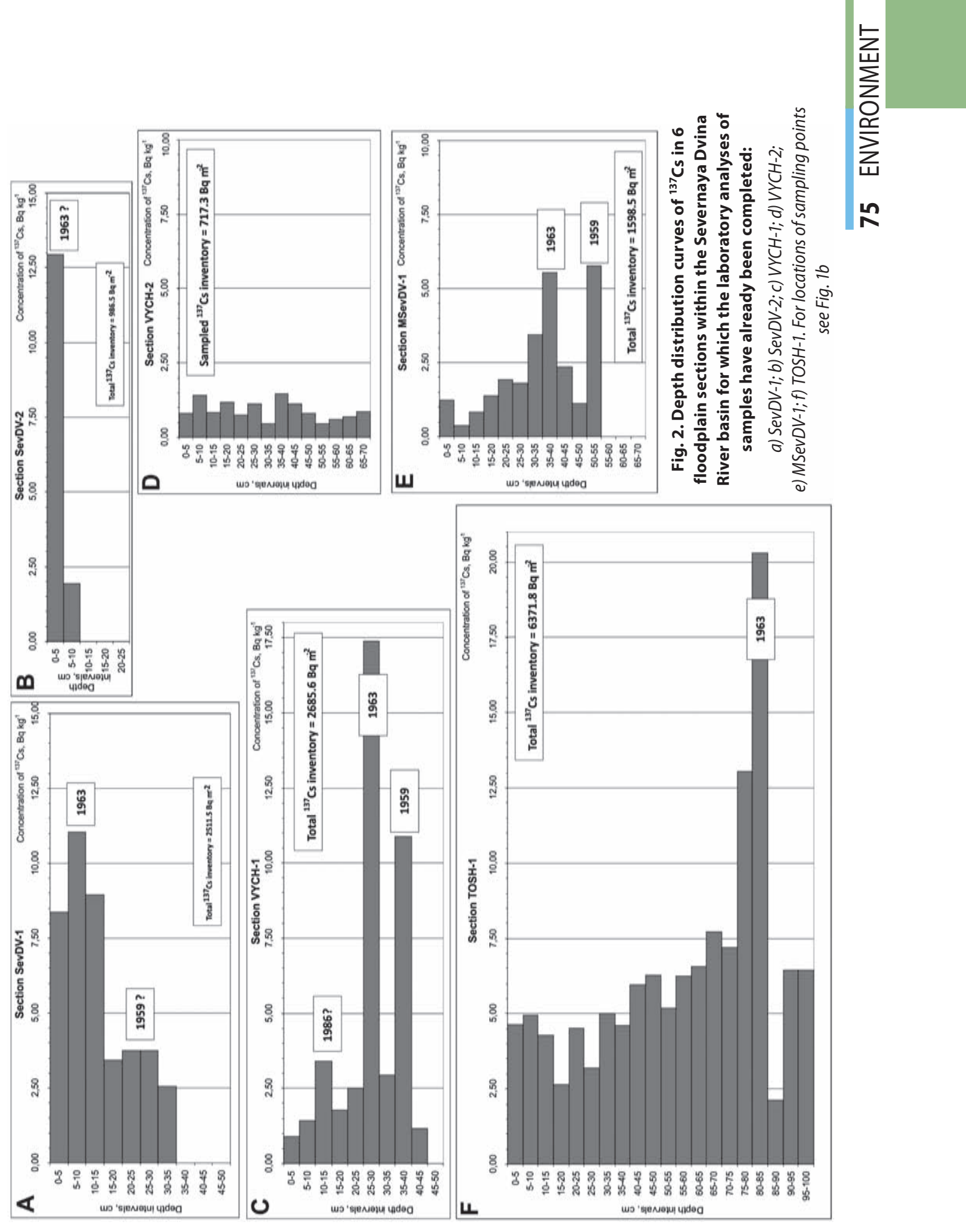
The last section (TOSH-1, Fig. 2f) is characterized by very high ${ }^{137} \mathrm{Cs}$ inventory, exceeding by about 3 times the regional fallout values reported (Atlas.., 1998), even though in this section it is also obvious that the sampling depth was insufficient to reach the base of the ${ }^{137} \mathrm{Cs}$ depth distribution. It must be noted that, despite certain fluctuations, no systematic upward decrease of the isotope concentration in deposited sediment occurs in the section TOSH-1 (Fig. 2f). It is obvious from very high ${ }^{137} \mathrm{Cs}$ inventory, shape and depth penetration of the isotope distribution curve that the main sediment source in this case is not bank erosion upstream but soil erosion on arable valley slopes.

From the presented ${ }^{137} \mathrm{Cs}$ depth distribution curves, reliable sediment stratigraphy and reconstruction of overbank deposition rates can be carried out for the 4 sections with clearly distinctive peaks (SevDV-1, VYCH-1, MSevDV-1 and TOSH-1, Fig. 2). For the section SevDV-1 (Fig. 2a) deposition rates can be reconstructed for periods of 1954-1959 $\left(\approx 2.0 \mathrm{~cm}\right.$ year $\left.{ }^{-1}\right), 1959-1963\left(\approx 4.0 \mathrm{~cm}\right.$ year $\left.{ }^{-1}\right)$ and 1963-2007 (approximately estimated as $\approx 0.17 \mathrm{~cm}$ year ${ }^{-1}$, but, more likely, has been gradually decreasing since 1963 until now, when it is close to 0). For the section SevDV-2 (Fig. 2b) it is not possible to establish timing of the event of floodplain surface erosion by floating ice, therefore it cannot be used for estimation of overbank deposition rates. For the section VYCH-1 (Fig. 2C) we can calculate sedimentation rates for the 4 time intervals: 1954-1959 ( $\approx 1.5 \mathrm{~cm}$ year $\left.^{-1}\right), 1959-1963$ $\left(\approx 2.5 \mathrm{~cm}\right.$ year $\left.{ }^{-1}\right), 1964-1986\left(\approx 0.7 \mathrm{~cm}\right.$ year $\left.{ }^{-1}\right)$ and 1986-2008 $\left(\approx 0.5 \mathrm{~cm}\right.$ year $\left.{ }^{-1}\right)$. For the section VYCH-2 (Fig. 2d) it can only be suggested that all the overbank sediment layer has been formed after 1986 at average deposition rate $>3.5 \mathrm{~cm}$ year $^{-1}$. For the section MSevDV-1 (Fig. 2e) deposition rate was close to 0 between 1954 and 1959, $\approx 2.1 \mathrm{~cm}$ year $^{-1}$ for 1959-1963 period and $\approx 0.8 \mathrm{~cm}$ year ${ }^{-1}$ for 1963-2008 period. For the section TOSH-1 (Fig. 2f) average overbank deposition rate can be approximately estimated only for period of 1963-2008 $\left(\approx 1.8 \mathrm{~cm}\right.$ year $\left.{ }^{-1}\right)$, because depth of the lower peak and base of the ${ }^{137} \mathrm{Cs}$ depth distribution are unknown.

Summarizing the above data, it can be stated that comparatively high spatial-temporal variations of sedimentation rates are observed between the sampled floodplain sections within the Severnaya Dvina River basin. It can be suggested that floodplain deposition rates for sampled reaches of the Severnaya Dvina and Vychegda Rivers (except for the youngest floodplain segment at $\mathrm{VYCH}-2$ ) generally decreased from $\approx 1.5-$ $4.0 \mathrm{~cm}$ year $^{-1}$ between 1954 and 1963 to $\approx 0-1.0 \mathrm{~cm}$ year $^{-1}$ at present. Certainly, it is not reliable to use data from 3 individual points (sections SevDV-1, MSevDV-1 and VYCH-1 because sections SevDV-2 and VYCH-2 do not provide estimates of deposition rates) for any large-scale extrapolations of floodplain sedimentation rates. Nevertheless, they provide some insight on floodplain overbank sedimentation rates for relatively young floodplain segments located in proximity to the main channels. It is believed that the observed tendencies reflect normal natural evolution of floodplain segments where sampling sites were selected. Gradual floodplain aggradation results in less frequent and prolonged inundation and, as a consequence, in the decrease of overbank deposition rates. Representativeness of the point-estimated values for the entire floodplain segments is supported by the fact that all of the sections sampled are characterized by uniform structure of upper laminated fine sediment layer, without any abrupt changes in lamination along its strike. Main source of fine sediment in that case is erosion of floodplain banks located further upstream.

The highest average overbank deposition rate for the period of 1963-2008 $\left(\approx 1.8 \mathrm{~cm}\right.$ year $\left.{ }^{-1}\right)$ was detected at the Toshnya River floodplain (Fig. 1b, 2f), which represents the smallest of the rivers sampled. It is located in the territory with relatively high area of cultivated lands, which can locally represent an important sediment source. Such floodplain aggradation rate is very significant for such 
a relatively small river. However, it must be borne in mind that most of the sediment originating from soil erosion on cultivated land and delivered into small or medium rivers becomes redeposited in their valleys. For example, for the Volga River basin it has been estimated that only less than 10\% of catchment-derived sediment reaches valleys of rivers with a drainage basin area exceeding 10000 km² [Sidorchuk, 1995; Sidorchuk \& Golosov, 2003]. In addition, in the case of the upper tributaries of the Suhona River (including the Toshnya River), most of the suspended sediment delivered from these tributaries into the main river is intercepted and redeposited in the area where the Suhona River valley crosses the former glacial lake bottom and has wide inherited floodplain. Therefore, floodplain deposition data for the Toshnya River are applicable only for small and medium rivers of the most densely populated and agriculturally developed southwestern part of the Severnaya Dvina River basin. This sediment source is almost completely disconnected from the further parts of the fluvial sediment cascade.

\section{Geochemical properties of overbank sediments}

Geochemical properties of overbank deposits can now be evaluated basing on results of the laboratory analyses of 90 samples from the same 6 floodplain sections discussed above. Average and maximum values of concentrations of the 9 selected heavy metals in the analyzed samples are presented in the Table 1, where those are also compared with the global clarke concentrations, global clarke for clayey deposits (as dominant surface materials

Table 1. Total content of selected heavy metals in floodplain overbank deposits of the Severnaya Dvina

River basin in 6 analyzed sediment sections in comparison with global clarke concentrations, global clarke concentrations in clay deposits and maximum allowable concentrations (MAC) for soils according to the Russian health and safety standards $(\mathrm{mg} / \mathrm{kg}$ ). Values in excess of the MAC (AAC) are shown in bold

\begin{tabular}{|c|c|c|c|c|c|}
\hline \multirow{2}{*}{$\begin{array}{l}\text { Heavy } \\
\text { metals }\end{array}$} & \multirow{2}{*}{ Global clarke } & \multirow{2}{*}{$\begin{array}{l}\text { Global clarke in } \\
\text { clay deposits }\end{array}$} & \multirow{2}{*}{$\operatorname{MAC}(A A C)^{1}$} & \multicolumn{2}{|c|}{$\begin{array}{l}\text { Overbank deposits of the Severnaya } \\
\text { Dvina River basin }(n=90)^{2}\end{array}$} \\
\hline & & & & Average & Maximum \\
\hline $\mathrm{Mn}$ & $200-500$ & 700 & 1500 & 431 & 3210 \\
\hline $\mathrm{Cu}$ & $20-25$ & 60 & 55 & 11 & 30 \\
\hline $\mathrm{Zn}$ & 60 & 90 & 100 & 39 & 114 \\
\hline $\mathrm{Pb}$ & $20-30$ & 20 & 30 & 5 & 13 \\
\hline $\mathrm{Ni}$ & $20-30$ & 60 & 85 & 23 & 76 \\
\hline Co & $8-10$ & 20 & $(30-40)$ & 7 & 22 \\
\hline V & 120 & 100 & 150 & 32 & 98 \\
\hline $\mathrm{Cd}$ & 0.3 & 0.5 & (2) & 0.1 & 0.7 \\
\hline $\mathrm{Cr}$ & 110 & $50-70$ & $(100-200)$ & 25 & 68 \\
\hline $\mathrm{Sr}$ & 220 & $90-120$ & - & 30 & 136 \\
\hline As & 6.6 & $4-9$ & (10) & 4.0 & 15.7 \\
\hline
\end{tabular}

${ }^{1}$ Approximate allowable concentrations (AAC) are given in brackets for elements if MACs are not stated in the Russian health and safety standards;

${ }^{2} n$ - number of samples. 
within the Severnaya Dvina River basin) and the maximum allowable concentrations (MAC) for soils according to the Russian health and safety standards. It is obvious from the presented data that general situation as regards the sediment pollution by heavy metals within the Severnaya Dvina River basin is much better than that in the Central European Russia. In most of the samples concentrations of pollutants were substantially below the MACs and comparable to the clarke concentrations for clay fractions (Table 1, Fig. 3).

However, substantially increased concentrations of certain heavy metals (in particular $\mathrm{Mn}, \mathrm{Zn}$ and $\mathrm{As}$ ) exceeding the MAC values have been detected in individual sediment layers at sampling sites located immediately downstream from industrial centers. Those can point either to relatively short-term pollutant dumpings, for example, associated with failures of the industrial waste treatment systems, or to more prolonged periods of continuous input of pollutants into the fluvial system. For example, Fig. 3 shows comparison of $\mathrm{Mn}, \mathrm{Zn}$ and As content in overbank sediment of the Severnaya Dvina River lower reach downstream (section SevDV-1 - Fig. 3a-c) and upstream (section SevDV-2 - Fig. 3d-f) from the largest industrial center - Arkhangelsk City. At the upstream section no excess concentrations of the selected heavy metals above the MAC values have been observed, while downstream there are 4 successive samples with concentrations of As and 1 sample with concentration of $\mathrm{Zn}$ exceeding the MAC values (Fig. 3b, c). All these 5 samples are located below the ${ }^{137} \mathrm{Cs}$ maximum penetration depth and, thus, can be attributed to the first half of $20^{\text {th }}$
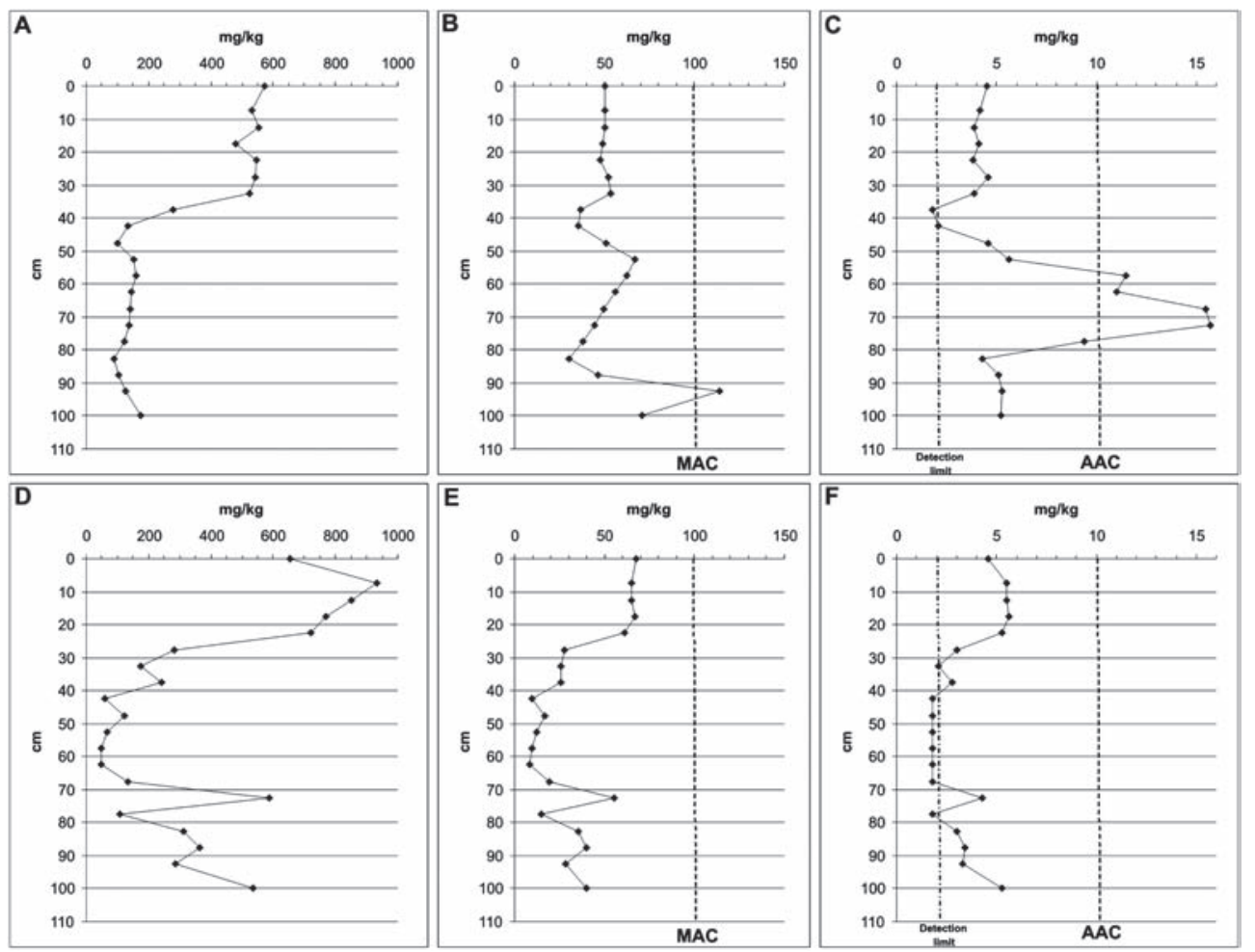

Fig. 3. Depth distribution curves of the selected heavy metals in floodplain sections located downstream - SevDV-1 (a - Mn, b - Zn, c - As) - and upstream - SevDV-2 (d - Mn, e - Zn, f - As) from the Arkhangelsk City. The MAC value for $M n$ is $1500 \mathrm{mg} / \mathrm{kg}$. For locations of sampling points see Fig. $1 \mathrm{~b}$ 
century. Another 3 successive samples with concentrations of $\mathrm{Mn}$ significantly exceeding the MAC value have been found in the lower part $(90-105 \mathrm{~cm})$ of the section MSevDV-1, which can also be attributed to the same period of time.

In general overbank floodplain deposits sampled within the Severnaya Dvina River basin are characterized by substantial variability ofconcentration of variouschemical elements, both within a single section and between sections, as can also be exemplified by Fig. 3. Nature of this variability is most likely not uniform. For example, practically identical patterns of depth distribution of Mn, Zn and As in section SevDV-2 (Fig. 3d-f) can most likely be explained by variation of finer fractions of sediment to which these heavy metals are preferentially bound. On the other hand, the observed peaks of $\mathrm{Zn}$ and As concentrations in section SevDV-1 (Fig. 3a-c), located in $<45 \mathrm{~km}$ downstream can be explained only by anthropogenic impact. Further investigations may also allow us to determine different geochemical signals in overbank sediment originated from geologically different parts of the Severnaya Dvina River basin, thus making it possible to evaluate relative contribution of different sediment sources and their temporal variability [Carter et al., 2003; Collins \& Walling, 2004]. Combination of ${ }^{137}$ Cs-based stratigraphy, geochemical analysis and quantitative information on sediment fluxes will allow evaluating the level of sedimentassociated contamination of the river basin area, determining point sources of pollution and making some conclusions on delivery of particle-bound pollutants into the Arctic Ocean.

\section{CONCLUSIONS}

Most of the Severnaya Dvina River basin area is characterized by very low level of agricultural development. Therefore, sediment production from soil and gully erosion on arable land has very minor contribution into the basin-scale fluvial sediment budget. Much more important contributors into sediment yield of main rivers within the basin are bank erosion directly on these rivers and sediment export from their smaller tributaries. The latter is also mainly originated from bed and bank erosion, as small river catchments are mostly forested. Main temporarily sediment sink within the Severnaya Dvina River basin fluvial system is represented by vast flood plains of largest rivers characterized by comparatively active reworking as a result of interaction of bank erosion, overbank deposition and lateral floodplain accretion by bedform stabilization.

Application of the ${ }^{137} \mathrm{Cs}$ radioactive tracer has allowed establishing recent overbank sediment stratigraphy and reconstructing aggradation rates for several floodplain sections for 1-4 time intervals since 1954. It has been shown that the sampled relatively young floodplain segments of large rivers experience natural tendency of decreasing aggradation rates associated with declining frequency and magnitude of their inundation as a result of gradual increase of surface elevation above the channel. Main source of fine sediment in that case is erosion of floodplain banks located further upstream. In contrast, floodplain of the relatively small Toshnya River located in area characterized by intensive agricultural development experiences continuous aggradation without noticeable tendency of decrease, with main sediment source being soil erosion on cultivated valley slopes. Evaluation of geochemical properties of the Severnaya Dvina River basin overbank sediments for the same floodplain sections has shown that general situation is much better than in the Central European Russia, in particular as regards the sediment pollution by heavy metals. In most of the samples concentrations of pollutants were below the MACs and comparable to the clark concentrations for clay fractions. However, substantially increased concentrations of certain heavy metals (in particular $\mathrm{Mn}, \mathrm{Zn}$ and $\mathrm{As}$ ) exceeding 
the MAC values have been detected in individual sediment layers at sampling sites located immediately downstream from industrial centers. Those can point to relatively short-term pollutant dumpings, for example, associated with failures of the industrial waste treatment systems, or to more prolonged periods of continuous input of pollutants into the fluvial system.

Further research perspectives will be in quantitative assessment of contribution of different sediment sources on one hand and different pollution sources on the other hand. Main attention will be paid to collection of measurements of bank erosion rates for largest rivers of the basin, expanding database on recent floodplain aggradation rates and searching for independent sources of this information. The established geochemical properties of overbank sediments will be compared with those of main sediment and pollution sources. Long-term data on suspended sediment yields will be used to quantify fluxes of major particle-bound pollutants and compare their contribution into the Arctic Ocean pollution with available information on solute fluxes.

\section{ACKNOWLEDGEMENTS}

This research was carried out within the framework of the IPY project no. 317 "Flux of sediment-associated chemical elements in rivers draining to the Arctic Ocean", associated with the IPY project no. 104: "The Arctic Hydra project". Research group from the Moscow State University has had an additional financial support from the RFBR (project no. 10-0500976) and the President of the Russian Federation support program for young researchers (project no. MK-8023.2010.5) and for leading scientific schools (project no. NS-3284.2010.5).

\section{REFERENCES}

1. Alexeevskiy, N.I. (1998). River sediment formation and transport. Moscow, MSU Publ., 202 p. (in Russian).

2. Atlas of Caesium deposition on Europe after the Chernobyl accident. (1998). Published by the Office for official publications of the European Communities in Luxembourg. 63 plates, 65 text pages.

3. Belyaev, V.R., Golosov, V.N., Ivanova, N.N., Markelov, M.V., and Tishkina, E.V. (2005). Human-accelerated soil redistribution within an intensively cultivated dry valley catchment in southern European Russia. In: Sediment Budgets I (Proceedings of Symposium S1 held during the Seventh IAHS Scientific Assembly at Foz do Iguacu, Brasil, April 2005). IAHS Publ. 291, pp. 11-20.

4. Bobrovitskaya, N. (1996). Long term variations in mean erosion and sediment yield from the rivers of the former Soviet Union. In: Walling, D.E. and Webb, B.W. (Eds.), Erosion and Sediment Yield: Global and Regional Perspectives, IAHS Publ. 236, pp. 407-413.

5. Bogen, J., Bølviken, B., and Ottesen, R.T. (1992). Environmental studies in Western Europe using overbank sediment. In: Erosion and Sediment Transport Monitoring Programmes in River Basins, (Proceedings of the Oslo Symposium), IAHS Publ. 210, pp. 317-325.

6. Carter, J., Owens, P.N., Walling, D.E., and Leeks, G.J.L. (2003). Fingerprinting suspended sediment sources in a large urban river system. The Science of the Total Environment, 314-316: 513-534.

7. Collins, A.L., and Walling, D.E. (2004). Documenting catchment suspended sediment sources: problems, approaches and prospects. Progress in Phys. Geography, 28(2): 159-196. 
8. Dedkov, A.P., and Mozzherin, V.I. (1984). Erosion and sediment yield on Earth. Kazan Univ. Publ., 264 p. (in Russian).

9. Holmes, R.M., McCelland, J.W., Peterson, B.J., Shiklomanov, I.A., Shiklomanov, A.I., Zhulidov, A.V., Gordeev, V.V. and Bobrovitskaya, N. (2002). A circumpolar perspective on fluvial sediment flux to the Arctic ocean. Global Biogeochemical Cycles, 16 (4): 1-45.

10. Langedal, M., and Ottesen, R.T. (1998). Airborne pollution of five drainage basins in eastern Finnmark, Norway: an evaluation of overbank sediments as sampling medium for environmental studies and geochemical mapping. Water, Air and Soil Pollution, 101: 377-398.

11. Makkaveev, N.I. (1955). The river channel and erosion in its basin. RAN Publ., Moscow, 343 p.

12. Michel, H., Chitty, D., Barci-Funel, G., Ardisson, G., Appleby, P.G., and Haworth, E. (2002). Comparaison of ${ }^{210} \mathrm{~Pb}$ chronology with ${ }^{238,239-240} \mathrm{Pu},{ }^{241} \mathrm{Am}$ and ${ }^{137} \mathrm{Cs}$ sedimentary record capacity in a lake system. In: Environmental Changes and Radioactive Tracers, pp. 213-222.

13. Milliman, J.D., and Meade, R.H. (1983) World-wide delivery of river sediment to the oceans. J. Geol., 95: 751-762.

14. Milliman, J.D., and Syvitski, J.P.M. (1992). Geomorphic / tectonic control of sediment discharge to the ocean: the importance of small mountainous rivers. J. Geol., 100: 325-344.

15. Murray, A.S., Marten, R., Johnston, A., and Martin, P. (1987). Analysis for naturally occurring radionuclides at environmental concentrations by gamma spectrometry. J. Radioanal. Nucl. Chem., 115: 263-288.

16. Ottesen, R.T., Bogen, J., Bølviken, B., and Volden, T. (1989). Overbank sediment: a representative sampling medium for regional geochemical mapping. J. Geochem. Explor., 32: 257-277.

17. Reznikov, P.N., Chalov, R.S. (2005). Sediment yield and conditions of channel formation on rivers of the Severnaya Dvina basin. Geomorphologiya, 2: 73-85 (in Russian).

18. Ridgway, J., Flight, D.M.A., Martiny, B., Gomez Caballero, A., Macias Romo, C., and Greally, K. (1995). Overbank sediments from central Mexico: an evaluation of their use in regional geochemical mapping and in studies of contamination from modern and historical mining. Applied Geochemistry, 10 (1): 97-109.

19. Salomons, W., and Brils, J. (eds.). (2004). Contaminated Sediments in European River Basins. Report of the SedNet, $70 \mathrm{p}$.

20. Schumm, S.A. (1977). The fluvial system. Wiley Interscience, N.Y. and London, 338 p.

21. Sidorchuk, A.Y. (1995). Erosion-sedimentation processes on the Russian Plain and the problem of aggradation in the small rivers. In: Water Resources Management and Problems of Fluvial Science, AVN Publ., Moscow, Russia, pp. 74-83 (in Russian).

22. Sidorchuk, A.Y., and Golosov, V.N. (2003). Erosion and sedimentation on the Russian Plain, II: the history of erosion and sedimentation during the period of intensive agriculture. Hydrol. Process, 17 (16): 3347-3358. 
23. Syvitski, J.P.M., Vörösmarty, C.J., Kettner, A.J., and Green, P. (2005). Impact of Humans on the Flux of Terrestrial Sediment to the Global Coastal Ocean. Science 308 (5720): 376-380.

24. Walling, D.E., Quine, T.A., and He, Q. (1992). Investigating Contemporary Rates of Floodplain Sedimentation. In: Carling, P.A., Petts, G.E. (Eds.), Lowland Floodplain Rivers: Geomorphological Perspectives, Wiley, Chichester, pp. 165-184.

25. Walling D.E., and He, Q. (1997). Use of fallout ${ }^{137}$ Cs in investigations of overbank sediment deposition on river floodplains. Catena, 29: 263-282.

26. Walling, D.E., and He, Q. (1998). The spatial variability of overbank sedimentation on river floodplains. Geomorphology, 24: 209-223.

27. Xie, X., and Hangxin, C. (2001). Global geochemical mapping and its implementation in the Asia-Pacufic Region. Applied Geochemistry, 16: 1309-1321.

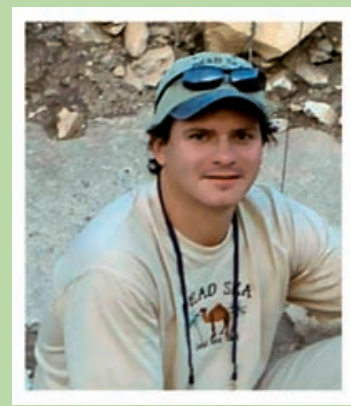

Vladimir R. Belyaev graduated from the Lomonosov Moscow State University in 1998, obtained the MSc. degree (Geomorphology and Environmental Change) at the University of Durham (UK) in 1999. He defended his PhD. dissertation at the Faculty of Geography of the Lomonosov Moscow State University in 2004. Currently he is a senior researcher at the Laboratory of Soil Erosion and fluvial processes. Main scientific interests: fluvial geomorphology, soil and gully erosion; GIS applications, use of remote sensing data and modeling in soil erosion and gully erosion studies; palaeogeomorphology of the Holocene. Main publications: A comparison of methods for evaluating soil redistribution in the severely eroded Stavropol region, southern European Russia. Geomorphology, 65, 2005 (co-authors Wallbrink, P.J., Golosov, V.N., Murray, A.S., Sidorchuk, A.Yu.); Stages of Late Holocene gully development in the Central Russian Plain. Int. J. of Sediment Research, 20 (3), 2005 (co-authors Eremenko, E.A., Panin, A.V., Belyaev, Yu.R.); Quantitative assessment of effectiveness of soil conservation measures using a combination of ${ }^{137} \mathrm{Cs}$ radioactive tracer and conventional techniques. Catena, 79, 2009 (co-authors Golosov, V.N., Kuznetsova, Y.S., Markelov, M.V.).

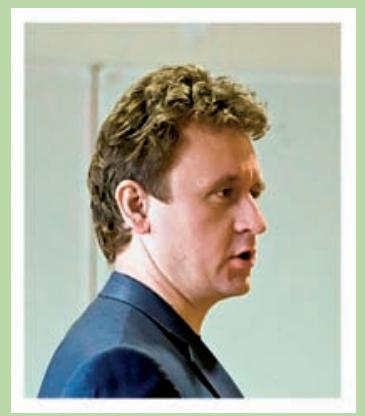

Alexander S. Zavadskiy graduated from the Lomonosov Moscow State University in 1997. He defended his PhD. dissertation at the Faculty of Geography of the Lomonosov Moscow State University in 2001. Currently he is a senior researcher at the Laboratory of Soil erosion and fluvial processes. Main scientific interests: river channel processes, channel deformations in various parts of the river network, regional analysis of channel processes, transformations of river channel behavior as a response to different types of human impact. Main publications: Morphological Characteristics of Free Bends. Int. J. of Sediment Research, 1999, Vol. 14, No. 3 (co-author Chalov, R.S.); River meanders. MSU Publ., 2004 (co-authors Chalov, R.S., Panin, A.V.); Natural deformations of the lower Moscow River channel and its transformations under intensive human impact. Geomorphologiya, 1, 2006 (co-author Kargapolova, I.N.). 

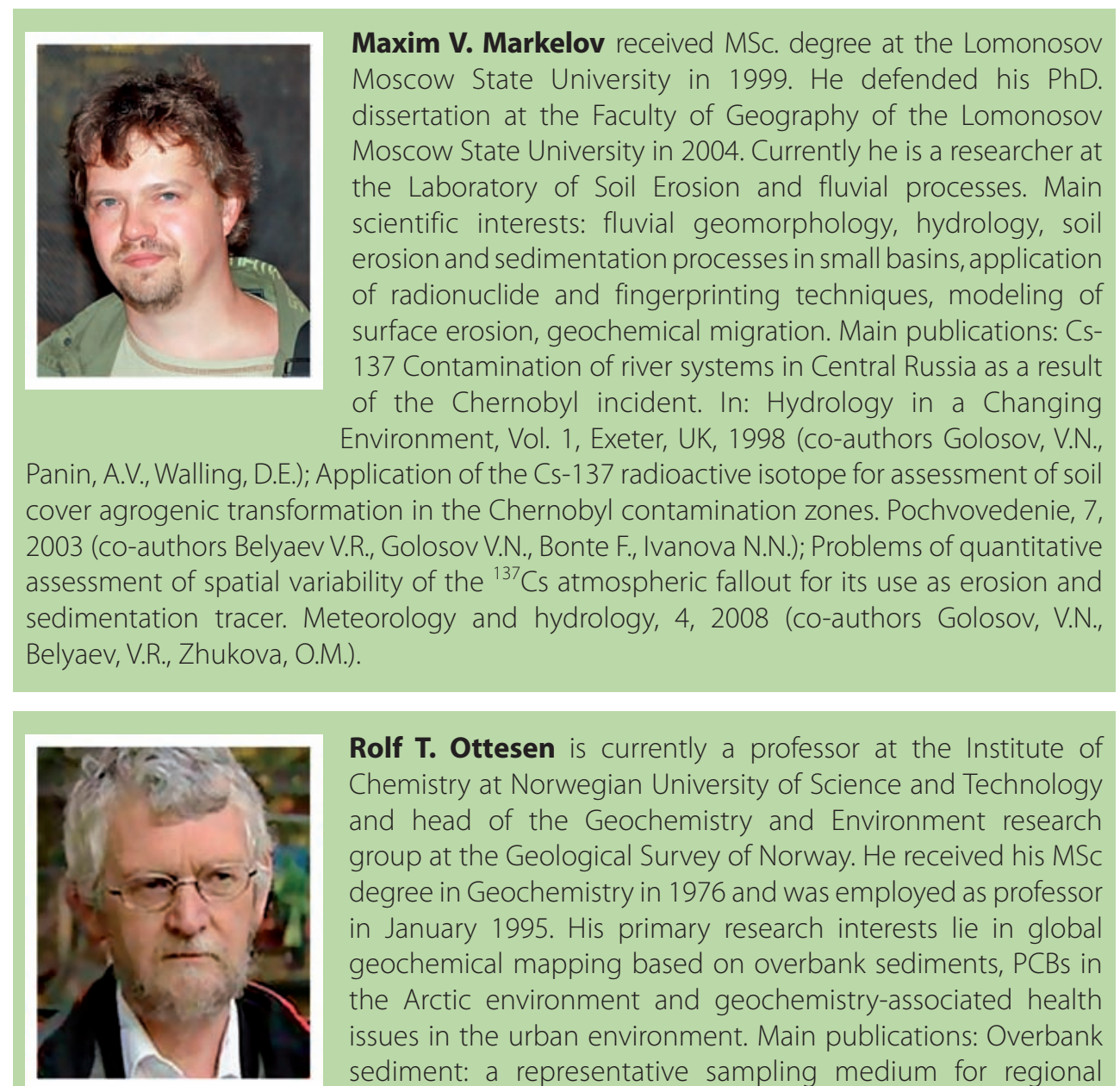

Rolf T. Ottesen is currently a professor at the Institute of Chemistry at Norwegian University of Science and Technology and head of the Geochemistry and Environment research group at the Geological Survey of Norway. He received his MSC degree in Geochemistry in 1976 and was employed as professor in January 1995. His primary research interests lie in global geochemical mapping based on overbank sediments, PCBs in the Arctic environment and geochemistry-associated health issues in the urban environment. Main publications: Overbank sediment: a representative sampling medium for regional geochemical mapping. J. Geochem. Explor., 32, 1989 (coauthors Bogen, J., Bølviken, B., Volden, T.); Geochemical atlas of Spitsbergen. Geological Survey of Norway, 2010. 154 pp. (co-author Bogen, J.J.); Mapping the chemical environment of urban areas. 2011. Wiley, 854 pp. (co-author).

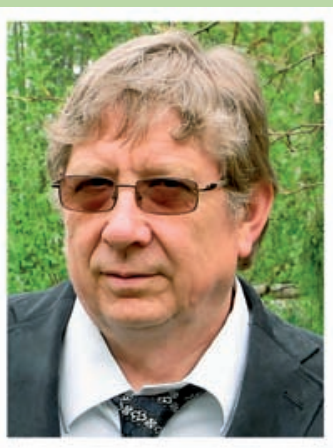

Jim J. Bogen is currently head of the Section of Sediment and Erosion at the Norwegian Water Resources and Energy Directorate and is a past President of ICCE/IAHS. He received his Ph.D. in 1976. Since 1996 he has been giving part-time lectures as a professor at the University of Svalbard. His primary research interests lie in area of erosion and sediment transport processes and particle-bound chemical elements. Main publications: Environmental studies in Western Europe using overbank sediment. In: Erosion and Sediment Transport Monitoring Programmes in River Basins. IAHS Publ. 210. 1992 (co-authors Bølviken, B., Ottesen, R.T.); Erosion and sediment transport in high Arctic rivers, Svalbard. Polar Research, 22 (2), 2003 (coauthor Bønsnes, T.E.); Overbank sediments: a natural bed blending sampling medium for large-scale geochemical mapping. Chemometrics and Intelligent Laboratory Systems, 74, 2004 (co-authors Bølviken, B., Jartun, J., Langedal, M., Ottesen, R.T. Volden, T.). 


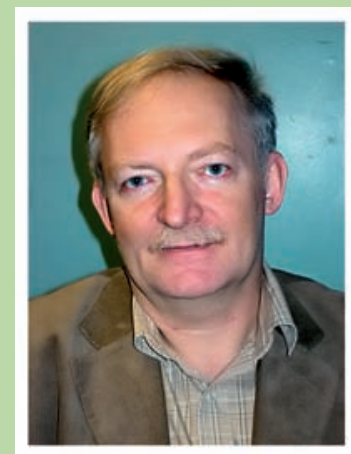

Valentin N. Golosov is a principal researcher at the Faculty of Geography, M.V. Lomonosov Moscow State University. The main topic of his study is sediment redistribution in the river basins. One of the main directions of his investigations is application of Cs-137 as a tracer for assessment of erosion and deposition rates in different parts of fluvial systems at various spatial scales. Sediment-associated pollutants redistribution is one of the latest directions of his research. Main publications: SedimentAssociated Chernobyl ${ }^{137} \mathrm{Cs}$ Redistribution in the Small Basins of Central Russia. In: Applied Geomorphology: Theory and Practice (Ed. R.J. Allison). John Wiley, Chichester 2002 (co-author Ivanova, N.N.); Erosion and deposition processes in the river basins of cultivated plains. Moscow: GEOS, 2006. 296 pp.; Century-scale stream network dynamics in the Russian Plain in response to climate and land use change. Catena, Vol. 66, Issue 1-2. 2006 (co-author Panin, A.V.).

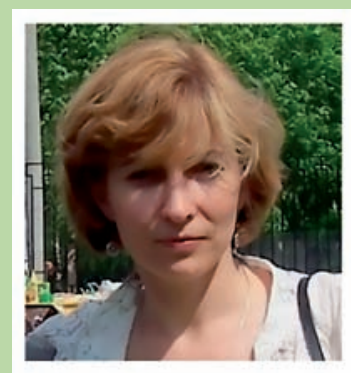

Elena N. Aseyeva is a researcher at the Faculty of Geography, M.V. Lomonosov Moscow State University. She received her PhD. degree in 2006. Her research interests include: geochemistry of river alluvium, geochemical mixing, geochemical classification of river basins, application of numerical methods for exploring geochemical signals in river sediments and floodplain soils as well as geochemistry of soils in background territories. Metals in particle size fractions and heavy metal mobile phases are of her special interest. Main publications: Drainage basin controls on geochemical heterogeneity of modern stream sediments in the Guadalhorce basin (Spain). IAHS publ. 288, 2004 (co-authors Kasimov, N.S., Kroonenberg, S.B., Weltje, G.J.); Basin organization of landscape and geochemical systems. In: Geography. Society and Environment. Vol. 2. Moscow, Gorodets Publ., 2004 (co-authors Kasimov, N.S., Kroonenberg, S.B.); Distribution of metals in particle size fractions in soils of a forested catena in the Smolensko-Moskovskaya Upland. Herald of Moscow State University, Series 5: Geography, 3, 2008 (co-author Samonova O.A.).

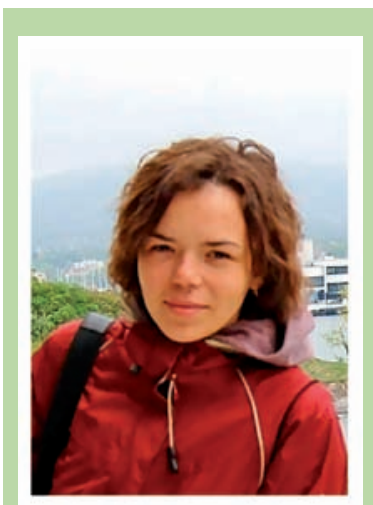

Yulia S. Kuznetsova received MSc. degree at the Lomonosov Moscow State University in 2007 and has just completed her post-graduate study. Her current position is a researcher at the Laboratory of Soil Erosion and fluvial processes. Main scientific interests: fluvial geomorphology, soil and gully erosion, fluvial network development, analysis of relief morphometry, GIS and modeling applications for studies of fluvial erosion and deposition. Main publications: Morphometric analysis of interfluve topography for scaling soil erosion rates from local to regional scales. In:Sediment dynamicsinchanging environments. IAHS Publ. 325, 2008 (co-author Golosov V.N.); Effect of topographic scale on the estimation of soil erosion rates using an empirical model. In: Sediment dynamics for a changing future. IAHS Publ. 337, 2010 (co-authors Belyaev V.R., Golosov V.N.). 